\title{
Gene Expression of Protease Inhibitors in Tomato Plants with Invasion by Root-Knot Nematode Meloidogyne incognita and Modulation of Their Activity with Salicylic and Jasmonic Acids
}

\author{
S. V. Zinovieva ${ }^{a, *}$, Zh. V. Udalova ${ }^{a}$, V. V. Seiml-Buchinger ${ }^{b, c}$, and F. K. Khasanov ${ }^{a}$ \\ ${ }^{a}$ Severtsov Institute of Ecology and Evolution, Russian Academy of Sciences, Moscow, 119071 Russia \\ ${ }^{b}$ Institute of Biology, Karelian Research Center, Russian Academy of Sciences, Petrozavodsk, 185910 Russia \\ ${ }^{c}$ Freie Universität Berlin, Institut für Biologie/Pflanzenphysiologie, Berlin, 14195 Germany \\ *e-mail:zinovievas@mail.ru \\ Received December 26, 2019; revised February 25, 2020; accepted February 28, 2020
}

\begin{abstract}
The expression of the genes encoding the inhibitors of serine (ISP) and cysteine proteinases (ICP) was studied in the roots of tomato plants resistant and susceptible to the root-knot nematode Meloidogyne incognita during infection and under the effects of signaling molecules: salicylic (SA) and jasmonic (JA) acids. It was shown that, upon infection, resistant plants are characterized by an increased accumulation of transcripts of the $I C P$ and $I S P$ genes at the stages of penetration and development in the roots, while the level of transcription does not change in susceptible plants. There was a significant decrease in nematode invasion in susceptible plants after treatment with SA or JA compared to untreated plants, which makes it possible to determine the role of the studied proteinase inhibitors in resistance induced by signaling molecules. It was revealed that an increase in expression of the genes of proteinase inhibitors is accompanied by inhibition of the reproductive potential and size of $M$. incognita females, as well as by a decrease in plant infection.
\end{abstract}

DOI: $10.1134 / \mathrm{S} 1062359021020175$

\section{INTRODUCTION}

The root-knot nematodes of the genus Meloidogyne (Göeldi, 1892) are among the most dangerous, highly adapted obligate parasites of root systems, which affect almost all species of higher plants (Moens et al., 2009). Their effect on plants is composed of mechanical and chemical damage, as well as using cellular contents as nutrients. During their evolution, root-knot nematodes have developed a highly specialized and unique way of existence in the roots of host plants. Larvae penetrate into roots, migrate in the conduction system, and induce the formation of specialized feeding sites, the so-called giant cells. A giant cell supplies larvae with nutrients required to complete their lifecycle. These nematodes induce gall formation on plant roots and affect the growth and physiological parameters of a host, reducing plant productivity. Similar to all parasitic nematodes, root-knot nematodes have a special stylet (lancet), which allows them to penetrate into plants and to feed. The main influencing factors of root-knot nematodes in altering the cellular structure and functions of the host are secretions from the esophageal glands, the cuticle surface, and the amphids, which include proteins and other biologically active molecules (effectors). The mechanical action of the stylet provides precise and localized deposition of the effectors of esophageal glands in host plant cells. The studies of the functional role of nematode effectors have confirmed their significance for many processes occurring in plants exposed to nematode invasion: migration through plant tissues, development and maintenance of feeding structures, and the defense response, as has been reported in some works (Gheysen and Mitchum, 2011, 2019; Haegeman et al., 2012; Rosso et al., 2012; Mitchum et al., 2013).

Proteases (proteinases), the proteolytic enzymes cleaving the inner peptide bonds of proteins and peptides, are a considerable part of effectors. Enzymatic hydrolysis of proteins and peptides (proteolysis) as a special form of biological control is one of the most important processes in the vital activity of organisms.

The most widespread and economically important species of root-knot nematodes is Meloidogyne incognita (Kofoid, White, 1919) Chitwood, 1949, a model species for studying the biology and relationship with plants and the processes of co-adaptation in the plant-nematode system. However, in spite of great success achieved in the past 10-15 years due to the development of unique methods of research, including methods for construction of biologically active recombinant DNA molecules, bioinformatics, genomics, etc., the relationship between these organisms and plants are still pretty much terra incognita. A 
significant accomplishment was to decode the genome of M. incognita (Abad et al., 2008), which became a vast source of information for better understanding of all factors associated with nematode parasitism. This nematode is known to possess almost all representative classes of proteinases described in the literature. Studies have shown that the degradome of the rootknot nematode $M$. incognita consists of 334 proteinases of different classes, making up $1.74 \%$ of all proteins encoded in the genome of this nematode. At the same time, 64 of all the identified proteinases contain the N-terminal signal peptide, which indicates their involvement in the secretory activity of nematodes (Bellafiore et al., 2008) and suggests their potential effect on host plants. Among them, there are two cathepsin-like cysteine proteinases (Neveu et al., 2003; Shingles, 2007), chymotrypsine-like serine proteinases (Rosso et al., 2012) and cathepsin D, an aspartic proteinase (Fragoso et al., 2005). Some aspartic proteinases are excreted by parasitizing nematodes into the apoplast of plants (Vieira et al., 2011).

Studies of the expression of the genes of the three major proteinases of $M$. incognita (aspartic (Mi-asp-1), serine (Mi-ser-1) and cathepsin L-type cysteine (Mi-cpl-1) showed considerable differences at all stages of nematode development (from the penetration of larvae into the roots to the reproductive stage), which was indicative of their different functions performed during the development (Antonino de Souza et al., 2013).

The functions of proteinases in plant parasitic nematodes were determined by the method for selective inactivation of gene expression by small interfering RNAs. This method showed the involvement of proteinases in many aspects of morphogenesis and physiology of plant cells, in degradation of the protective proteins of plants (Vieira et al., 2011), as well as in the specialized physiological processes of nematodes, like moulting (Craig et al., 2007) and embryogenesis (Britton and Murray, 2002; Hashmi et al., 2002).

The method of RNA interferences used in tobacco plants invaded by $M$. incognita, with suppression of the activity of the genes encoding aspartic (Mi-asp-1), serine $(M i$-ser- 1$)$, and cysteine $(M i-c p l-1)$ proteases in their roots, yielded data on the role of these proteinases in the development of nematodes in plant roots. It was shown that knockdown of the genes of the abovementioned proteases, which were excluded from the ration of parasitic nematodes, affected the size, reproduction, egg viability, and virulence in the progeny (Antonino de Souza et al., 2013).

In view of the significance of this class of enzymes with a broad range of metabolic functions in parasitehost interactions, proteinases can be considered as important targets for creating new crops with enhanced resistance to nematodes. The suppression of nematode development in plants with genes expressing proteinase inhibitors has been confirmed by many studies (Atkinson et al., 2009, 2012; Dutta et al., 2015; Ali et al., 2017; etc.).

Most likely, the results obtained in plants carrying the genes of proteinase inhibitors or expressing dsRNA for particular proteinases do not represent natural situations in the invaded plants but demonstrate that inhibitors capable of suppressing proteinase activities may be one of the factors of plant defense against nematode invasion. It seems that the suppression of enzyme activities by protein inhibitors is the most ancient (in evolutionary terms) way of regulation of proteolysis (Mosolov, 1983). This process is controlled by signal transduction cascades associated with transcription of the genes encoding these protein inhibitors (Koiwa et al., 1997). One of the causes of expression and accumulation of protease inhibitors (PIs) in the cells infected with various phytopathogens is activation of the signaling pathway mediated by salicylic (SA) or jasmonic (JA) acid (Vlot et al., 2009; Uehara et al., 2010). The data obtained previously in tomatoroot-knot nematode systems demonstrate the effects of SA or JA on plant resistance, exerting an inhibitory effect on the development and fertility of nematodes (Zinovieva et al., 2013; Vieira dos Santos et al., 2013).

Numerous studies have shown that the local and systemic accumulation of PIs is a component of the defense response initiated by wounding under exposure to pests or pathogens (Ryan, 1990; Birkenmeier and Ryan, 1998; Valuyeva and Mosolov, 2002). It has been shown that the inhibitors of serine proteinases I and II in tomatoes were deposited in endospermal cell walls and secretory cells of the root cap and were secreted into the environment. Hence, it was suggested that PIs can protect the growing root meristem from pathogenic microorganisms and other pests, including the nematodes affecting plant root system (Narváez-Vásquez et al., 1993). There are limited data on the role of PIs in the plant defense response to the invasion of phytoparasitic nematodes and the development of interrelationships in the nematode-plant system, and these data are contradictory (Rashed et al., 2008; Turra et al., 2009; Revina et al., 2012; Udalova et al., 2014). Let us note that the genes identified, the transcripts of which accumulate in tomato plants infected with the nematode Meloidogyne javanica, include the gene encoding the inhibitor of serine proteinase, which belongs to the structural superfamily of Kunitz-type inhibitors (SBTI), which in involved in protection of Solanaceae from fungal infections (Lambert et al., 1999).

The inhibitors were selected on the basis of available data on the major presence of serine and cysteine proteinases in the root-knot nematode organism and the presence of inhibitors of these proteinases in tomato roots (Turra et al., 2009; Castagnone-Sereno, 2011; Kovács et al., 2016).

This work was aimed at comparative analysis of the expression of the genes of serine and cysteine protein- 
Table 1. Primers for real-time PCR

\begin{tabular}{l|l|l}
\hline \multirow{2}{*}{ Gene } & \multicolumn{2}{|c}{ Nucleotide sequence $\left(5^{\prime} \ldots 3^{\prime}\right)$} \\
\cline { 2 - 3 } & \multicolumn{1}{|c}{ forward primer } & \multicolumn{1}{c}{ reverse primer } \\
$I S P$ & TCTTGGGTTCGGGATATG & GGGACATCTTGAATAGGC \\
Actin & GTGATGAGCCCAAGGCAAAT & GCCAATCCAGAAGATGGACAA \\
\hline
\end{tabular}

ase inhibitors in resistant and susceptible tomato plants under conditions of $M$. incognita invasion and exogenous effects of SA and JA, as well as elucidation of the significance of these inhibitors for plant resistance to nematodes, using morphophysiological indicators of the state of the population of root parasitic nematodes.

\section{MATERIALS AND METHODS}

The material for study was the closely related lines of tomato plants Lycopersicon esculentum L., the Shagane F1 hybrid resistant to infection by the root-knot nematode $M$. incognita and the sensitive Gamayun F1 hybrid. Plant seeds were superficially sterilized with $1 \% \mathrm{Ca}(\mathrm{OCl})_{2}$ solution. Plants were grown in plastic vessels with steamed soil in a climate test chamber at $25^{\circ} \mathrm{C}$, with the photoperiod L/D $=16: 8$. Samples were taken from invaded susceptible tomatoes cultivated in a greenhouse. Eggs were extracted from the galls formed by nematodes on the roots of these plants and incubated in distilled water; after hatching of larvae, plants were infected with a suspension of nematodes (3000 invasive larvae/plant). The number of nematodes in aliquots was counted under a light microscope. Plant infection and cultivation were performed by the standard techniques described previously (Udalova and Zinovieva, 2016).

The effects of signaling molecules (SA and JA) on the activity of PI genes were studied in the following solutions: SA, $7 \times 10^{-8} \mathrm{M}$, and JA, $5 \times 10^{-8} \mathrm{M}$ (Sigma, United States). Plant seeds were soaked for $2 \mathrm{~h}$ in SA or JA solutions at the concentrations mentioned above and then the two-week seedlings were sprayed immediately before the invasion $(7 \mathrm{~mL}$ of the solutions per plant). The control seeds and plants were treated with distilled water. Each experimental variant (healthy plants (control); invaded plants without the treatment; invaded + $\mathrm{JA}$; invaded + SA) was repeated tenfold.

The samples for molecular analysis were taken before the invasion, as well as at the key stages of nematode activity (days 1 and 3, mass penetration of larvae into roots; day 5 , formation of the feeding site (giant cells); day 20, active feeding and formation of mature adults). The roots of uninvaded plants were analyzed in the same periods of time.

The level of transcription of the PI genes was assessed by a real-time polymerase chain reaction
(PCR). The total RNA was isolated with an Extract RNA kit (Evrogen, Russia). The amount and quality of the total RNA were determined by capillary electrophoresis in the Experion system (Bio-Rad, United States). The total RNA was treated with DNAse (1 U) (Syntol, Russia). The first-strand cDNA was synthesized using reverse transcription with random hexaprimers (Evrogen, Russia). PCR was carried out by the standard protocol. The PCR efficiency (98\%) was assessed by the standard curve. The relative level of gene expression was calculated by the $\Delta \Delta \mathrm{Ct}$ method. cDNA samples taken from the plants not exposed to exogenous effects were used as a control. Actin was used as a reference gene. The design of DNA primers of the inhibitors of serine proteinases $(I S P)$ and the inhibitors of cysteine proteinases (ICP) was determined by Primer3 (http://primer3plus.com) (Table 1). Each experiment was repeated sixfold.

Nematode resistance in plants was assessed in each variant by the extent of root damage (the number of galls per root unit) and by the morphophysiological parameters of parasites (the size and fertility (number of eggs in ootheca)) on day 35 after the invasion. Additionally, the state of invaded plants was assessed by weight and height. Each variant was analyzed tenfold.

The data were statistically processed by ANOVA, SAS Version 6.0 (Statsoft Statistica). The data on the morphophysiological parameters of nematodes and the plant growth parameters were analyzed by the least significant difference (LSD): Fisher's test $(P \leq 0.05)$. The significant difference in gene expression between plants at each moment of time was determined by Duncan's test $(P \leq 0.05)$.

\section{RESULTS}

Expression of proteinase inhibitor genes in the roots of resistant and susceptible tomato plants in the period of pre-invasion. The results of study have shown that resistant and susceptible plants normally (in the absence of infection) possess active genes of serine and cysteine PIs with a low level of expression (Fig. 1).

There is no statistically significant difference in the level of expression of the PI genes in roots of resistant and susceptible plants (Fig. 1). The activities of the serine and cysteine proteinase genes were not different from each other either: gene expression was almost the same in both resistant and susceptible plants (Fig. 1). 

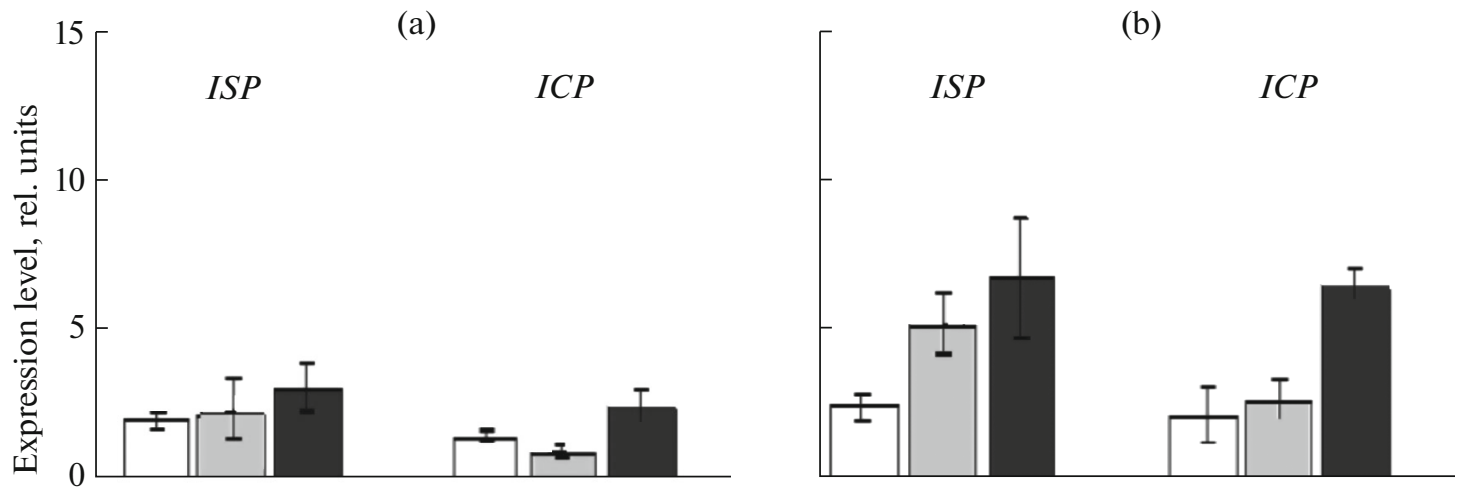

1

2

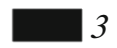

Fig. 1. Expression of the genes of the inhibitors of serine proteinases $(I S P)$ and cysteine proteinases $(I C P)$ in the roots of (a) resistant and (b) susceptible tomato plants (1) before infection with Meloidogyne incognita and after their treatment with (2) SA and (3) JA.

Exogenous treatment of plants with SA in the period of pre-invasion had different effects on PI gene expression in the roots of resistant and susceptible plants. In resistant plants, the number of transcripts was unchanged; in susceptible plants, the accumulation of gene transcripts of serine proteinase inhibitors increased twofold, but the activity of the genes of cysteine proteinase inhibitors remained at the level of the control untreated plants (Fig. 1).

The treatment with JA influenced gene expression in the period of pre-invasion: in the resistant variety, the content of gene transcripts of serine and cysteine proteinase inhibitors increased insignificantly compared to those in untreated plants (Fig. 1). The susceptible plants responded to JA as follows: the number of transcripts of both serine and cysteine PIs increased more than twofold compared to those in untreated plants.

Expression of proteinase inhibitor genes in the roots of resistant and susceptible tomato plants after $S A$ and $J A$ treatment and $M$. incognita invasion. Invasion of plants caused an increase in the activity of both PI genes. In resistant plants, there was a reliable increase in the level of transcripts compared to uninvaded plants already on day 3. The level of transcripts varied throughout the life cycle, and the maximum accumulation of transcripts in resistant plant tissues occurred in the period of nematode feeding by day 20 (Fig. 2). The content of transcripts of the serine and cysteine PIs by that period in the roots of invaded plants was higher 3.5- and 3-fold, respectively, than in uninvaded plants in the same period.

The response of susceptible plants to nematode infection was different from that of resistant plants. The expression of both cysteine and serine PI genes did not change upon infection: the accumulation of transcripts in infected plants was comparable with that in uninfected plants (Fig. 2). The tendency towards enhanced expression of the genes of serine proteinase inhibitors was observed on day 5 after the invasion; however, on day 20 of infection, by the moment of active feeding of the nematodes, the activities of both genes were lower compared to those in uninfected plants (Fig. 2).

After the infection of resistant plants treated with SA, the dynamics of accumulation of gene transcripts in the roots was similar to that observed in untreated infected plants (Fig. 2). The infection of SA-treated susceptible plants was accompanied by an enhanced level of expression of both genes, which was maintained throughout the entire period of nematode development in the roots (days 5-20). In this period, the level of transcripts was twofold higher compared to uninvaded plants (Fig. 2). It should be noted that the dynamics and level of gene transcript accumulation are comparable with those in the infected resistant plants.

JA treatment had a noticeable effect on gene expression in tomato roots during the invasion. The accumulation of gene transcripts, as well as serine and cysteine PIs, in resistant plants was much higher already $24 \mathrm{~h}$ after the invasion: 3.6- and 4.2-fold, respectively, compared to untreated plants (Fig. 2). The increased level of transcripts was observed until day 5, followed by an insignificant decrease (Fig. 2). By day 20, the expression of both genes was similar to that in untreated plants.

Upon the infection of susceptible JA-treated plants, the PI genes were greatly expressed in the period from day 3 to day 20 . In contrast to infected resistant plants, the peak of gene expression in susceptible plants was observed on day 5 after the invasion (Fig. 2).

Thus, the data presented on the modulation of expression of the genes of serine and cysteine protein- 
(a)

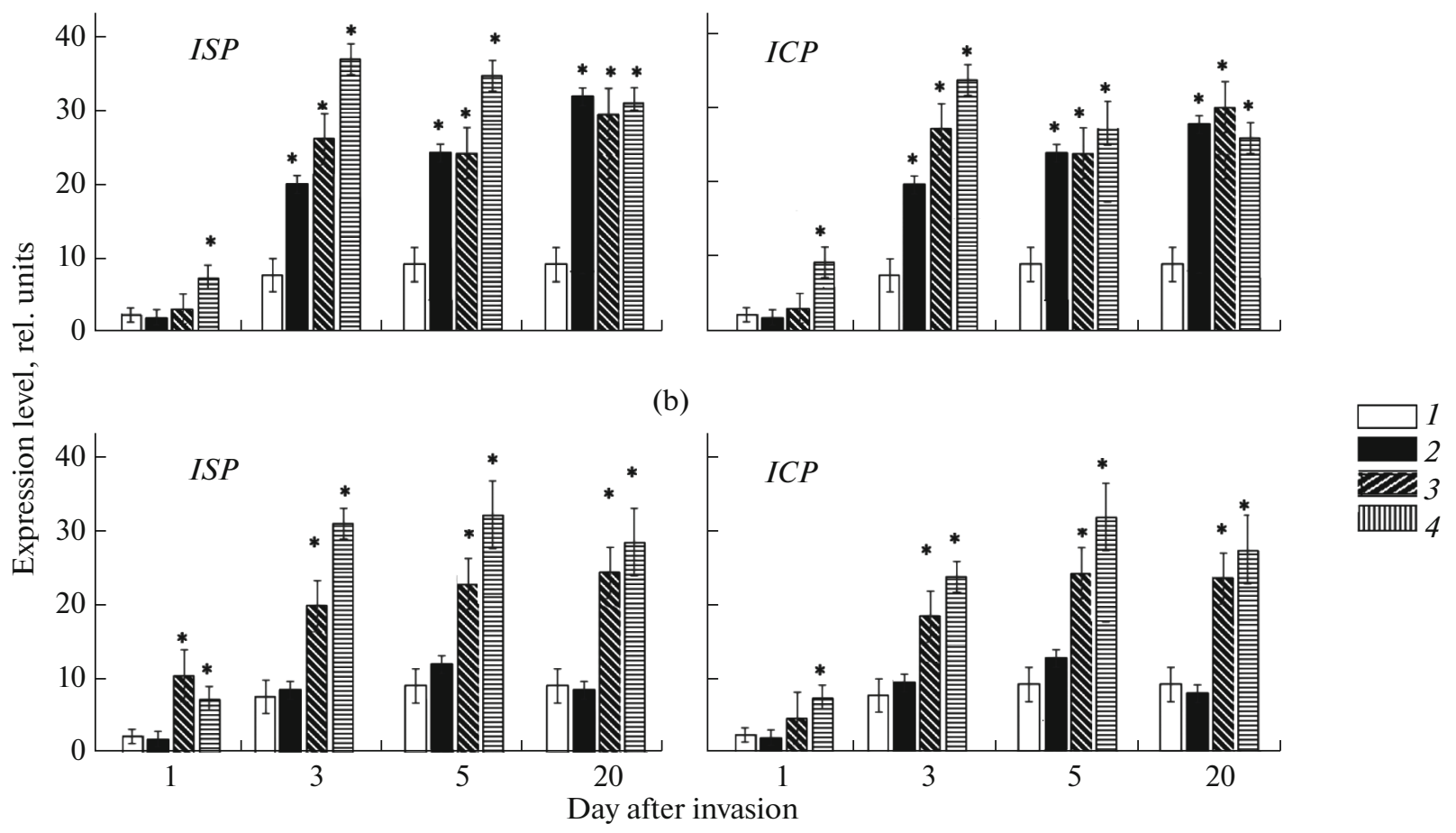

Fig. 2. Expression of the genes of inhibitors of serine proteinases (ISP) and cysteine proteinases (ICP) in the roots of (a) resistant and (b) susceptible tomato plants (1) before the infection with Meloidogyne incognita, (2) after the infection and treatment with (3) SA or (4) JA. * Significant differences (at $P \leq 0.05$ ) in gene expression between healthy and invaded plants.

ase inhibitors at different stages of nematode development and under different treatments apparently indicate the change in the functional activity of enzymes proper, which can exert a direct effect on the proteinases of the parasite.

Morphophysiological parameters of root-knot nematodes from susceptible plants treated with SA and JA. The studies of plants invaded by root-knot nematodes have shown that the treatment with SA or JA resulted in a lower level of infection in the roots of tomatoes susceptible to the root-knot nematode (the number of galls on the roots decreased by 45.6 and $31.1 \%$, respectively); at the same time, the mass of the aerial parts of plants was noticeably greater compared to that in untreated plants (Table 2).

In the treated plants, nematodes developed more slowly as could be judged by their sizes: they were smaller than in the untreated plants, by $19 \%$ in the case of JA and by $11 \%$ in the case of SA. The fertility of nematodes also decreased: the average number of eggs in oothecas was less by 15 and $32 \%$ for SA and JA treatment, respectively.

\section{DISCUSSION}

PIs are one of the groups of the PR (PathogenesisRelated Proteins) family, which are currently considered as one of the most important strategies of plant protection from pathogens (Ali et al., 2018). These proteins are induced in plants in response to the effects of pathogens under certain stress conditions. They have been classified into several groups (from PR-1 to PR-17) based on their amino acid sequences and biochemical functions. PIs belong to the group of PR-6 proteins. This group includes inhibitors of all known types of proteinases (serine, cysteine, aspartic proteases, and metalloproteases). Previous studies have shown that the level of the $P R-6$ gene transcripts and the dynamics of their activity under the root-knot (M. incoignita) and cyst-forming (Globodera rostochiensis) nematode invasion of tomato or potato plants, respectively, were different in nematode-resistant plants. The increased activity of these genes in the period of nematode development and reproduction indicated the potential role of the enzymes of this group as one of the main components of plant defense against invasion (Lavrova et al., 2017a, 2017b; SeimlBuchinger et al., 2019). The data of the present study demonstrate the potential involvement of two PI classes, serine and cysteine, in this process, as well as the modulation of their activity by the biogenic elicitors: jasmonic and salicylic acids.

The results have shown that, in spite of the presence of active genes of serine and cysteine proteinase inhibitors in the roots of healthy plants, infected resistant plants demonstrate intensive accumulation of the 
Table 2. Development of susceptible tomato plants and morphophysiological parameters of the nematode Meloidogyne incognita under conditions of treatment with salicylic acid (SA) and jasmonic acid (JA)

\begin{tabular}{l|c|c|c|c|c}
\hline \multicolumn{1}{c|}{ Plant } & $\begin{array}{c}\text { Mass of above- } \\
\text { ground organs, }\end{array}$ & Plant height, cm & Gall number/plant & $\begin{array}{c}\text { Number of eggs } \\
\text { in ootheca }\end{array}$ & $\begin{array}{c}\text { Size of females, } \\
\mathrm{mm}^{2}\end{array}$ \\
\hline Healthy & $59.3 \pm 4.2$ & $62.3 \pm 12.5$ & - & - & - \\
Invaded & $38.2 \pm 5.3$ & $58.8 \pm 8.2$ & $759 \pm 68$ & $158 \pm 24$ & $0.336 \pm 0.021$ \\
SA-treated & $135.7 \pm 15.6$ & $146.4 \pm 22.4$ & - & - & - \\
$\begin{array}{l}\text { SA-treated } \\
\text { invaded }\end{array}$ & $103.6 \pm 12.3$ & $117.0 \pm 13.5$ & $413 \pm 53$ & $135 \pm 26$ & $0.30 \pm 0.012$ \\
JA-treated & $68.2 \pm 9.2$ & $73.6 \pm 10.4$ & - & - & - \\
JA-treated & $67.2 \pm 8.7$ & $70.4 \pm 11.4$ & $523 \pm 45$ & $108 \pm 21$ & $0.272 \pm 0.019$ \\
invaded & 24.7 & 18.3 & 73 & 26 & 0.023 \\
LSD $(P \leq 0.05)$ & & & & & \\
\hline
\end{tabular}

LSD is the least significant difference at $P \leq 0.05 ;( \pm m)$ is the standard deviations from the mean value of the character; $n=10$; “ - " is the absence of data in healthy plants.

transcripts of these genes at the stages of penetration into and development in the roots, but there are no significant changes in the activity of these genes in susceptible plants. The differences revealed in the dynamics of PI gene expression are in agreement with our previous data on the expression of the $M i-1.2$ gene determining tomato resistance to root-knot nematodes, which increased in the roots of resistant plants with nematode infection and did not vary in susceptible plants (Lavrova et al., 2016, 2017b). Enhanced expression of the $M i-1.2$ resistance gene at the early stages of nematode parasitism (penetration of larvae into roots, formation of feeding sites (giant cells)) allows the timely recognition of parasite invasion by resistant plants, and they activate the protective signaling cascades of reactions resulting in high expression of the PI genes, which locally limits the spread of the parasite and the possibility of its normal development. The absence of changes in the activity of the PI genes in susceptible plants exposed to invasion indicates the absence of development of timely protective response and therefore creates favorable conditions for nematode development.

The results of earlier studies have shown that SA and JA are signaling molecules influencing the protective system under biotic stresses, including phytoparasitic nematodes (Cooper et al., 2005; Halim et al., 2006; Bhattarai et al., 2008; Molinary et al., 2008; Zinovieva et al., 2013; Fan et al., 2015; Yang et al., 2018). Exogenous application of these compounds considerably regulates the expression of many protective genes in plants (Stintzi et al., 2001; Fujimoto et al., 2011; Molinary et al., 2014).

Our previous studies have shown that exogenous treatments with SA and JA have no significant effect on the pattern and level of expression of the Mi-1.2 gene in the roots of resistant tomato plants (Lavrova et al., 2016; Seiml-Buchinger et al., 2019). The results of the present study demonstrate that exogenous treatments with SA or JA in the period of pre-invasion at the concentrations used also exert an insignificant effect on the pattern and level of PI gene expression in the roots of resistant tomato plants. They are characterized by low gene activity in the period of pre-invasion, followed by a rapid increase in expression level upon nematode infection. This result demonstrates that resistant plants under normal conditions (in the absence of invasion) actually make no transcriptomelevel response to external factors. This is probably due to the fact that the effects of SA or JA are aimed at inducing host protective properties, which are already sufficiently active in resistant plants.

The results show that susceptible plants are characterized by very low PI activation upon infection. However, they may have an immune potential realized under conditions of particular exogenous treatments, e.g., with SA or JA. These compounds cause an increase in the level of PI gene transcription in the roots of susceptible plants in the period of pre-invasion and stimulate an enhanced level of expression during the subsequent nematode invasion. It should be specially emphasized that generally the dynamics of gene activity in the roots of treated susceptible plants after infection shows similarity to resistant plants, though the peak of gene transcription is less marked than in genetically resistant plants. Nevertheless, in the case of infection, such plants are already capable of intercellular recognition of the effectors of nematode larvae, signal transduction to the genome, and timely activation of defense responses. The effects of SA and JA on the transcription activity of the studied genes in susceptible plants also indicate the role of these mole- 
cules in the development of induced resistance of tomatoes to nematode infection. The JA treatment of plants exerts a stronger effect on PI gene expression compared to SA treatment, because JA functions as a mobile signal for PI expression in distant plant tissues (Zinovieva et al., 2013).

This study has demonstrated considerably reduced nematode invasion in susceptible plants treated with SA or JA before the invasion, as compared to untreated plants, which indicates their improved immune status and makes it possible to determine the role of the studied PI-genes in the resistance induced by signaling molecules. The findings show that the expression of the PI genes under exposure to SA and JA is accompanied by a change in their reproductive potential, size, and the degree of infestation. This fact is in agreement with the previously published data showing that knockdown of the genes of these proteinases affects nematode reproduction and the virulence of the progeny (Antonino de Souza et al., 2013). In addition, susceptible plants infected with $M$. incognita were characterized by reduced biomass. Nematode parasitism results in lower water and nutrient uptake, which can lead to the flow of carbohydrates to the roots, as is necessary for nematode development and laying eggs by adult females, and hence to the impairment of plant growth (Amarasinghe and Dalugoda, 2009; Maleita et al., 2012). The treatment of susceptible plants with SA or JA before invasion contributed to an increase in their biomass, which is also evidence of reduced pathogenic effects of invasion.

The expression of PI genes at different stages of nematode development in the tissues of resistant and SA- or JA-primed plants has shown that the enhanced functional activity of these enzymes is associated mainly with the sedentary period of development (days 5-20), when nematodes feed and become sexually mature adults, followed by egg formation and laying eggs in an egg-sac. The expediency of increasing the activity of serine and cysteine proteinase inhibitors in plant roots as a defense response in this period is probably related to suppression of the activity of the respective nematode proteinases performing particular functions in embryogenesis, feeding, and maturation of eggs (Antonino de Souza et al., 2013). It is known that nematodes, while parasitizing, excrete some proteinases into the plant apoplast (Vieira et al., 2011), and this fact indicates their active participation in pathogenesis. Therefore, it is quite clear that the plant began to use its own PIs to neutralize the proteinases from phytopathogens in response to nematode invasion during evolution.

\section{CONCLUSIONS}

The development of root-knot nematodes in plant tissues is largely determined by the activity of proteinase inhibitors detected in plants at all stages of parasite development in plant roots and demonstrates the prospects of the methods of plant protection on their basis. One of the mechanisms of increasing plant resistance to nematodes can be the modulation of PI activity in plant tissues by agents providing long-term induction of their activity, in particular, the signal molecules of SA or JA. Exogenous treatment with SA and JA plays the role of priming for susceptible plants, which leads to mobilization of protective functions of plants, including the modulation of PI gene expression, which allows regulation of tomato plant resistance to nematode infection. Exogenous treatments enhance the transcription of protective genes in susceptible plants, prepare organisms for forthcoming stress conditions, and contribute to the development of induced resistance to the phytoparasitic nematode by mechanisms similar to genetic resistance.

Taking into account the great number of proteases acting at different stages of nematode development, the maximum success in creating nematode-resistant plants can be achieved by using several genes with functional properties associated with the parameters of vital activity of the parasite such as feeding, rates of development, and reproduction.

\section{FUNDING}

This work was carried out within the framework of state assignment no. 0109-2018-0066.

\section{COMPLIANCE WITH ETHICAL STANDARDS}

Conflict of interest. The authors declare that they have no conflict of interest.

Statement on the welfare of animals. All applicable international, national, and/or institutional guidelines for the care and use of animals were followed.

\section{OPEN ACCESS}

This article is licensed under a Creative Commons Attribution 4.0 International License, which permits use, sharing, adaptation, distribution and reproduction in any medium or format, as long as you give appropriate credit to the original author(s) and the source, provide a link to the Creative Commons license, and indicate if changes were made. The images or other third party material in this article are included in the article's Creative Commons license, unless indicated otherwise in a credit line to the material. If material is not included in the article's Creative Commons license and your intended use is not permitted by statutory regulation or exceeds the permitted use, you will need to obtain permission directly from the copyright holder. To view a copy of this license, visit http://creativecommons.org/licenses/by/4.0/.

\section{REFERENCES}

Abad, P., Gouzy, J., Aury, J.M., Castagnone-Sereno, P., Danchin, E.G., Deleury, E., Perfus-Barbeoch, L., Anthouard, V., Artiguenave, F., Blok, V.C., Caillaud, M.C., Coutinho, P.M., Dasilva, C., De Luca, F., Deau, F., Esqui- 
bet, M., Flutre, T., Goldstone, J.V., Hamamouch, N., Hewezi, T., Jaillon, O., Jubin, C., Leonetti, P., Magliano, M., Maier, T.R., Markov, G.V., McVeigh, P., Pesole, G., Poulain, J., Robinson-Rechavi, M., Sallet, E., Ségurens, B., Steinbach, D., Tytgat, T., Ugarte, E., van Ghelder, C., Veronico, P., Baum, T.J., Blaxter, M., Bleve-Zacheo, T., Davis, E.L., Ewbank, J.J., Favery, B., Grenier, E., Henrissat, B., Jones, J.T., Laudet, V., Maule, A.G., Quesneville, H., Rosso, M.N., Schiex, T., Smant, G., Weissenbach, J., and Wincker, P., Genome sequence of the metazoan plant-parasitic nematode meloidogyne incognita, Nat. Biotechnol., 2008, vol. 26, no. 8, pp. 909-915.

https://doi.org/10.1038/nbt.1482

Ali, M.A., Azeem, F., Abbas, A., Joyia, F.A., Li, H., and Dababat, A.A., Transgenic strategies for enhancement of nematode resistance in plants, Front. Plant Sci., 2017, vol. 8, p. 750 .

https://doi.org/10.3389/fpls

Ali, S., Ganai, B.A., Kamili, A.N., Bhat, A.A., Mir, Z.A., Bhat, J.A., Tyagi, A., Islam, S.T., Mushtaq, M., Yadav, P., Rawat, S., and Grover, A., Pathogenesis-related proteins and peptides as promising tools for engineering plants with multiplestress tolerance, Microbiol. Res., 2018, vols. 212213, pp. 29-37.

https://doi.org/10.1016/j.micres.2018.04.008

Amarasinghe, L.D. and Dalugoda, Y.S., Susceptibility of seven tomato (Lycopersicon esculentus) varieties to rootknot nematode, Meloidogyne incognita, Pest. Technol., 2009, vol. 3, no. 1, pp. 40-44.

Antonino de Souza, J.D., Jr., Ramos Coelho, R., Tristan Lourenço, I., da Rocha Fragoso, R., Barbosa Viana, A.A., Pepino de Macedo, L.L., Mattar da Silva, M.C., Gomes Carneiro, R.M., Engler, G., Janice de Almeida-Engler, and Grossi-de-Sa, M.F., Knocking down Meloidogyne incognita proteases by plant-delivered dsRNA has negative pleiotropic effect on nematode vigor, PLoS One, 2013, vol. 8, no. 12. e85364.

https://doi.org/10.1371/journal.pone.0085364

Atkinson, H.J., Urwin, P.E., and Hussey, R.S., Plant biotechnology and control, in Root-Knot Nematodes, Perry, R.N., Moens, M., and Starr, J.L., Eds., Wallingford, Oxfordshire: CAB International, 2009, pp. 338-362.

Atkinson, H.J., Lilley, C.J., and Urwin, P.E., Strategies for transgenic nematode control in developed and developing world crops, Curr. Opin. Biotechnol., 2012, vol. 23, pp. 251256.

https://doi.org/10.1016/j.copbio.2011.09.004

Bellafiore, S., Shen, Z., Rosso, M.-N., Abad, P., Shih, P., and Briggs, S.P., Direct identification of the Meloidogyne incognita secretome reveals proteins with host cell reprogramming potential, PLoS Pathog., 2008, vol. 4, no. 10. e 1000192.

https://doi.org/10.1371/journal.ppat.1000192

Bhattarai, K.K., Xie, Q.G., Mantelin, S., Bishnoi, U., Girke, T., Navarre, D.A., and Kaloshian, I., Tomato susceptibility to root-knot nematodes requires an intact jasmonic acid signaling pathway, Mol. Plant Microbe Interact., 2008, vol. 21, pp. 1205-1214.

https://doi.org/10.1094/MPMI-21-9-1205

Birkenmeier, G.F. and Ryan, C.A., Wound signaling in tomato plants. evidence that $\mathrm{ABA}$ is not a primary signal for defense gene activation, Plant Physiol., 1998, vol. 117, pp. $687-693$.

https://doi.org/10.1104/pp.117.2.687

Britton, C. and Murray, L., A cathepsin 1 protease essential for Caenorhabditis elegans embryogenesis is functionally conserved in parasitic nematodes, Mol. Biochem. Parasitol., 2002, vol. 122, pp. 21-33.

https://doi.org/10.1016/S0166-6851(02)00066-X

Castagnone-Sereno, P., Deleury, E., Danchin, E.G.J., Perfus-Barbeoch, L., and Abad, P., Data-mining of the Meloidogyne incognita degradome and comparative analysis of proteases in nematodes, Genomics, 2011, vol. 97, pp. 29-36.

Cooper, W.R., Jia, L., and Goggin, L., Effects of jasmonate-induced defenses on root-knot nematode infection of resistant and susceptible tomato cultivars, J. Chem. Ecol., 2005, vol. 31, pp. 1953-1967.

https://doi.org/10.1007/s10886-005-6070-y

Craig, H., Isaac, R.E., and Brooks, D.R., Unravelling the moulting degradome: new opportunities for chemotherapy?, Trends Parasitol., 2007, vol. 23, pp. 248-253.

https://doi.org/10.1016/j.pt.2007.04.003

Dutta, T.K., Papolu, P.K., Banakar, P., Choudhary, D., Sirohi, A., and Rao, U., Tomato transgenic plants expressing hairpin construct of a nematode protease gene conferred enhanced resistance to root-knot nematodes, Front. Microbiol., 2015, vol. 6, p. 260.

https://doi.org/10.3389/fmicb.2015.00260

Fan, J.W., Hu, C.L., Zhang, L.N., Li, Z.L., Zhao, F.K., and Wang, S.H., Jasmonic acid mediates tomato's response to root knot nematodes, J. Plant Growth Regul., 2015, vol. 34, pp. 196-205.

https://doi.org/10.1007/s00344-014-9457-6

Fragoso, R.R., Batista, J.A., Neto, O.B., and Grossi de Sá, M.F., Isolation and characterization of a cDNA encoding a serine proteinase from the root-knot nematode Meloidogyne incognita, Exp. Parasitol., 2005, vol. 110, pp. 123-133.

https://doi.org/10.1016/j.exppara.2005.02.010

Fragoso, R.R., Lourenco, I.T., Batista, J.A., Oliveira-Neto, O.B., Silva, M.C., Rocha, T.L., Coutinho, M.V., and Grossi-de-Sa, M.F., Meloidogyne incognita: molecular cloning and characterization of a cDNA encoding a cathepsin D-like aspartic proteinase, Exp. Parasitol., 2009, vol. 121, pp. 115-123.

https://doi.org/10.1016/j.exppara.2008.09.017

Fujimoto, T., Tomitaka, Y., Abe, H., Tsuda, S., Futai, K., and Mizukubo, T., Expression profile of jasmonic acid-induced genes and the induced resistance against the rootknot nematode (Meloidogyne incognita) in tomato plants (Solanum lycopersicum) after foliar treatment with methyl jasmonate, J. Plant Physiol., 2011, vol. 168, pp. 1084-1097. https://doi.org/10.1016/j.jplph.2010.12.002

Gheysen, G. and Mitchum, M.G., How nematodes manipulate plant development pathways for infection, Curr. Opin. Plant Biol., 2011, vol. 14, pp. 415-421.

https://doi.org/10.1016/j.pbi.2011

Gheysen, G. and Mitchum, M.G., Phytoparasitic nematode control of plant hormone pathways, Plant Physiol., 2019, vol. 179, pp. 1212-1226.

https://doi.org/10.1104/pp.18.01067 
Haegeman, A., Mantelin, S., Jones, J.T., and Gheysen, G., Functional roles of effectors of plant-parasitic nematodes, Gene, 2012, vol. 492, pp. 19-31.

https://doi.org/10.1016/j.gene. 2011.10.040

Halim, A., Vess, D., and Scheel, S., The role of salicylic acid and jasmonic acid in pathogen defence, Plant Biol., 2006, vol. 8, pp. 307-313.

https://doi.org/10.1055/s-2006-924025

Hashmi, S., Britton, C., Liu, J., Guiliano, D.B., Oksov, Y., and Lustigman, S., Cathepsin 1 is essential for embryogenesis and development of Caenorhabditis elegans, J. Biol. Chem., 2002, vol. 277, pp. 3477-3486.

https://doi.org/10.1074/ jbc.M106117200

Koiwa, H., Bressen, R.A., and Hasegawa, P.M., Regulation of protease inhibitors and plant defense, Trends Plant Sci., 1997, vol. 2, pp. 379-384.

https://doi.org/10.1016/S1360-1385(97)90052-2

Kovács, J., Poór, P., Szepesi, A., and Tari, I., Salicylic acid induced cysteine protease activity during programmed cell death in tomato plants, Acta Biol. Hung., 2016, vol. 67, pp. $148-158$.

https://doi.org/10.1556/018.67.2016.2.3

Lambert, K.N., Ferrie, B.J., Nombela, G., Brenner, E.D., and Williamson, V.M., Identification of genes whose transcripts accumulate rapidly in tomato after root-knot nematode infection, Physiol. Mol. Plant Pathol., 1999, vol. 55, pp. 341-348.

Lavrova, V.V., Udalova, Zh.V., Matveeva, E.M., Khasanov, F.K., and Zinovieva, S.V., $M i-1$ gene expression in tomato plants under root-knot nematode invasion and treatment with salicylic acid, Dokl. Biochem. Biophys., 2016, vol. 471, pp. 413416.

https://doi.org/10.1134/S1607672916060107

Lavrova, V.V., Matveeva, E.M., and Zinovieva, S.V., Expression of genes, encoded defense proteins, in potato plants infected with the cyst-forming nematode Globodera rostochiensis (Wollenweber 1923) Behrens, 1975 and modulation of their activity during sort-term exposure to low temperatures, Biol. Bull. (Moscow), 2017a, vol. 44, no. 2, pp. $128-136$.

https://doi.org/10.1134/S1062359017020108

Lavrova, V.V., Zinovieva, S.V., Udalova, Zh.V., and Matveeva, E.M., Expression of $P R$ genes in tomato tissues infected by nematode Meloidogyne incognita (Kofoid et White, 1919) Chitwood, 1949, Dokl. Biochem. Biophys., 2017b, vol. 476, pp. 306-309.

https://doi.org/10.1134/S1607672917050064

Maleita, C.M.N., Curtis, R.H.C., Powers, S.J., and Abrantes, I.M., Inoculum levels of Meloidogyne hispanica and $M$. javanica affect nematode reproduction, and growth of tomato genotypes, Phytopathol. Mediterr., 2012, vol. 51, pp. 566-576.

https://doi.org/10.14601/Phytopathol_Mediterr-9740

Mitchum, M.G., Hussey, R.S., Baum, T.J., Wang, X., Elling, A.A., Wubben, M., and Davis, E.L., Nematode effector proteins: an emerging paradigm of parasitism, New Phytol., 2013, vol. 199, pp. 879-894.

https://doi.org/10.1111/nph.12323

Moens, M., Perry, R.N., and Starr, J.L., Meloidogyne species-a diverse group of novel and important plant para- sites, in Root-Knot Nematodes, Perry, R.N., Moens, M., and Starr, J.L., Eds., Wallingford: L CAB International, 2009, pp. 1-17.

Molinari, S., Saliciylic acid as an elicitor of resistance to root-knot nematodes in tomato, Acta Hort. (ISHS), 2008, vol. 78, pp. 119-126.

Molinari, S., Fanelli, E., and Leonetti, P., Expression of tomato salicylic acid (SA)-responsive pathogenesis-related genes in Mi-1-mediated and SA-induced resistance to rootknot nematodes, Mol. Plant Pathol., 2014, vol. 15, pp. 255264.

https://doi.org/10.1111/Mpp.12085

Mosolov, V.V., Protein Inhibitors as Regulators of Proteolytic Processes, Moscow: Nauka, 1983.

Narváez-Vásquez, J., Franceschi, V.R., and Ryan, C.A., Proteinase-inhibitor synthesis in tomato plants: evidence for extracellular deposition in roots through the secretory pathway, Planta, 1993, vol. 189, pp. 725-726. www.jstor.org/stable/23382113.

Neveu, C., Abad, P., and Castagnone-Sereno, P., Molecular cloning and characterization of an intestinal cathepsin $\mathrm{L}$ protease from the plant-parasitic nematode Meloidogyne incognita, Physiol. Mol. Plant Pathol., 2003, vol. 63, pp. 159165.

https://doi.org/10.1016/j.pmpp.2003.10.005

Revina, T.A., Udalova, Zh.V., Zinovieva, S.V., and Valueva, T.A., Inhibitors of trypsin and chymotrypsin in the roots and leaves of tomatoes infected with root-knot nematode, in $\mathrm{Po}$ tato Growing: Coll. Scientific. Proceedings/RUE "Scientific and Practical Center of the National Academy of Sciences of Belarus for Potato and Fruit and Vegetable Growing, 2012, no. 20, pp. 119-124.

Rosso, M.N., Hussey, R.S., Davis, E.L., Smant, G., Baum, T.J., Abad, P., and Mitchum, M.G., Nematode effector proteins: targets and functions in plant parasitism, in Effectors in Plant-Microbe Interactions, Martin, F. and Kamoun, S., Eds., New York: Wiley-Blackwell, 2012, pp. 329-356.

Ryan, C.A., Protease inhibitors in plants: genes for improving defenses against insects and pathogens, Annu. Rev. Phytopathol., 1990, vol. 28, pp. 425-449.

https://doi.org/10.1146/annurev.py.28.090190.002233

Seiml-Buchinger, V.V., Zinovieva, S.V., Udalova, Zh.V., and Matveeva, E.M., Jasmonic acid modulates Meloidogyne incognita-tomato plant interactions, Nematology, 2019, vol. 21, pp. 171-180.

https://doi.org/10.1163/15685411-00003205

Shingles, J., Lilley, C.J., Atkinson, H.J., and Urwin, P.E., Meloidogyne incognita: molecular and biochemical characterisation of a cathepsin 1 cysteine proteinase and the effect on parasitism following RNAi, Exp. Parasitol., 2007, vol. 115, pp. 114-120.

https://doi.org/10.1016/j.exppara.2006.07.008

Stintzi, A., Weber, H., Reymond, P., Browse, J., and Farmer, E.E., Plant defense in the absence of jasmonic acid: the role of cyclopentenones, Proc. Natl. Acad. Sci. U. S. A., 2001, vol. 98 , pp. 12837-12842.

https://doi.org/10.1073/pnas.211311098

Turra, D., Bellin, D., Lorito, M., and Gebhardt, C., Genotype-dependent expression of specific members of potato 
protease inhibitor gene families in different tissues and in response to wounding and nematode infection, J. Plant Physiol., 2009, vol. 166, pp. 762-774.

https://doi.org/10.1016/j.jplph.2008.10.005

Udalova, Zh.V., Revina, T.A., Gerasimova, N.A., and Zinovieva, S.V., Participation of proteinase inhibitors in protection of tomato plants against root-knot nematodes, Dokl. Biol. Sci., 2014, vol. 458, pp. 726-729. https://doi.org/10.1134/S0012496614050147

Udalova, Zh.V., Zinovieva, S.V., and Khasanova, O.S., Influence of tomato resistance on morphophysiological diversity and population characteristics of root-knot nematode Meloidogyne incognita (Kofoid, White, 1919), Chitwood, 1949, Ross. Parazitol. Zh., 2016, vol. 36, no. 2, pp. 245-252.

Uehara, T., Sugiyama, S., Matsuura, H., Arie, T., and Masuta, C., Resistant and susceptible responses in tomato to cyst nematode are differentially regulated by salicylic acid, Plant Cell Physiol., 2010, vol. 51, pp. 1524-1536.

Valueva, T.A. and Mosolov, V.V., The role of proteolytic enzyme inhibitors in plant defense, Usp. Biol. Khim., 2002, vol. 42, pp. 193-216.

Vieira, P., Danchin, E.G., Neveu, C., Crozat, C., Jaubert, S., Hussey, R.S., Engler, G., Abad, P., Almeida-Engler, J., Castagnone-Sereno, P., and Rosso, M.-N., The plant apoplasm is an important recipient compartment for nematode secreted proteins, J. Exp. Bot., 2010, vol. 62, pp. 1241-
1253.

https://doi.org/10.1093/jxb/erq352

Vieira dos Santos, M.C., Curtis, R.H.C., and Abrantes, I., Effect of plant elicitors on the reproduction of the root-knot nematode Meloidogyne chitwoodi on susceptible hosts, Eur. J. Plant Pathol., 2013, pp. 193-202. https://doi.org/10.1007/S10658-012-0155-6

Vlot, A.C., Dempsey, D.A., and Klessig, D.F., Salicylic acid, a multifaceted hormone to combat disease, Annu Rev. Phytopathol., 2009, vol. 47, pp. 177-206.

https://doi.org/10.1146/annurev.phyto.050908.135202

Yang, Y.-X., Wu, C., Golam, G.J., Wu, C., Yang, Z., Wan, C., and Chen, J., Red light-induced systemic resistance against root-knot nematode is mediated by a coordinated regulation of salicylic acid, jasmonic acid and redox signaling in watermelon, Front. Plant Sci., 2018, vol. 9, p. 899.

https://doi.org/10.3389/fpls.2018.00899

Zinovieva, S.V., Vasyukova, N.I., Udalova, Zh.V., and Gerasimova, N.G., The participation of salicylic and jasmonic acids in genetic and induced resistance of tomato to Meloidogyne incognita (Kofoid and White, 1919), Biol. Bull. (Moscow), 2013, vol. 40, no. 3, pp. 297-303.

https://doi.org/10.1134/S1062359013030126

Translated by E. Makeeva 